
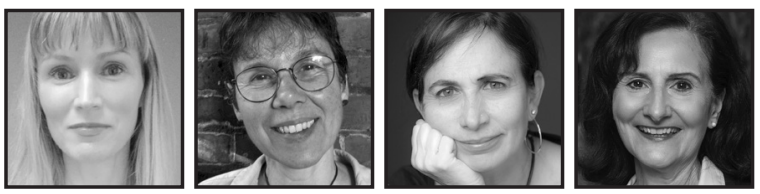

\title{
Exploring Methodological Inventiveness Through Collective Artful Self-Study Research
}

\author{
Kathleen Pithouse-Morgan, University of KwaZulu-Natal \\ Lesley Coia, Agnes Scott College \\ Monica Taylor, Montclair State University \\ Anastasia P. Samaras, George Mason University
}

\section{ABSTRACT}

We are teacher educators working in South Africa and the United States. Collectively we explored and extended our understanding of methodological inventiveness in selfstudy research through an artful process we have named "virtual polyvocal research jamming." We make explicit our extemporary, dialogic process, showing how we imagined and played with artful research practices: rich pictures, poetry, oral performance, and dance. Through collective analysis of our process and products, we share our learning about methodological inventiveness, highlighting how finding imaginative ways to express and make sense of insights can deepen and extend shared reflection, analysis, and communication in educational inquiry.

\section{Setting the Scene}

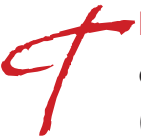

he aim of self-study research is to improve professional practice and contribute to the scholarship of professional learning and development (Berry, 2014). In the early 1990s, teacher educators whose work was largely based in previous forms of practitioner inquiry began to develop self-study research methodology, enabling them to: gain a better understanding of the intersections of their personal learning histories, cultures, and professional practices; develop self-understanding personally and professionally by examining their practice with colleagues; and consider how to reframe and improve professional practice 
(Bullough \& Gitlin, 1995; Loughran, 1996; Russell \& Korthagen, 1995). For self-study researchers, transforming understanding begins with the self, yet necessitates interaction with others to enrich and extend individual perspectives (LaBoskey, 2004). While some form of collaboration is essential in all self-study research, in collective selfstudy the collaborative dimension becomes a focus of the research (Davey \& Ham, 2009).

Self-study research requires both self-confidence and vulnerability as it confronts scholars on a personal level and triggers a heightened awareness of "the messiness, uncertainties, complexities, and elisions" (Samaras et al., 2014, p. 3) of professional practice. The self-study research process is embedded with both opportunities and risks, "countering professional development 'fixes'" (Latta \& Buck, 2007, p. 190) through documenting lived engagement with theory and practice. Discerning the impact of self-study research on students, colleagues, programs, and policy-making, "questioning the so what of self-study" (Loughran, 2010, p. 225) is at the forefront of the work of self-study researchers.

Increasingly, scholars across a range of academic and professional disciplines are engaging in self-study research (Pithouse-Morgan \& Samaras, 2015; Samaras et al., 2014; Coia \& Taylor, 2014). Self-study of professional practice thus continues to be reconceptualized, reconfigured, and reinvigorated in significant ways in response to diverse contexts and changing professional learning and development needs (Garbett \& Ovens, 2014). Accordingly, there is no single or prescribed self-study research method. The appropriate methods are those that inform the inquiry, with methodological inventiveness becoming increasingly characteristic of selfstudy research (Whitehead, 2004). Methodological inventiveness involves creative engagement to stimulate alternative, often artful, and transdisciplinary methods that contribute to generative ways of knowing, with wider implications for social change (Dadds \& Hart, 2001). In this article, we narrate how we-four teacher educators with diverse disciplinary backgrounds who work in four very different universities in South Africa and the United States-conducted collective artful self-study research to explore methodological inventiveness, combining varied methods and explanatory lenses to co-create a virtual bricolage (Pithouse-Morgan \& Samaras, 2014; Samaras et al., 2015; Badley, 2014) through nomadic jamming (Coia \& Taylor, 2014). Our research questioned what it means to enact creative engagement, both collectively and individually, in order to discover, develop, and better understand innovative possibilities within our practices as self-study researchers. Our initial guiding question was, "What has methodological inventiveness in self-study looked like for us individually and collectively?" As we found ourselves "jamming into the unpredictable" (Coia \& Taylor, 2014, p. 157), inviting the uncertain, listening to each other's individual experiences, and then taking cues from 
each other, a second guiding question emerged for us: "What is the process of virtual polyvocal research jamming in self-study?"

We begin this article by sharing our collaborative backgrounds, providing a historical context to our study. We then describe our collective self-study research process, detailing how we conceived and put into practice artful research practices. These are illustrated through examples of products from our exploration. Next, through an analysis of our process and products, we share what we have learned about methodological inventiveness. We conclude with our insights about the significance of this collaborative artful endeavour, highlighting possible implications and inspirations that our creative engagement might evoke for others.

\section{Our Collaborative Backgrounds}

We brought to our collective inquiry a rich history of self-study research conducted in duos. Kathleen and Anastasia are teacher educators involved in leading transdisciplinary self-study learning communities in their respective home countries of South Africa and the United States and with individuals who work in various disciplines inside and outside of teacher education. These related experiences brought them together in 2012 when they began to dialogue, chiefly through digital technologies, about facilitating transdisciplinary self-study learning communities with students and university faculty. They enacted a virtual bricolage self-study method using dialogic tools to generate, analyze, and represent data for their collaborative, arts-based self-study (Pithouse-Morgan \& Samaras, 2014). This initial collaboration led to the development of an edited book focusing on polyvocality-dialogic encounters with diverse ways of seeing and knowing -in professional learning through self-study research (PithouseMorgan \& Samaras, 2015).

Lesley and Monica have been working collaboratively for 15 years, during which time they have employed co/autoethnography (Coia \& Taylor, 2009), a methodology they developed and use to explore the deep connections between their practice, social identities, and histories. Co/autoethnography integrates the autobiographical characteristics of self-narrative within a dialogic context of collaborative researchers working together to extend and deepen reflection. In their work, Lesley and Monica compose stories drawn from their own past and present lived experiences as teacher educators, "jamming into the unpredictable" (Coia \& Taylor, 2014, p. 157) as they "write into each other's lives" (Taylor \& Coia, 2006, p. 61). 


\section{A Collective Artful Self-Study Research Process}

Collective self-study research offered us, as a newly formed quartet, a supportive space for a polyvocal exploration of methodological inventiveness. Individual contributions enhanced each other's learning as well as that of the group, making possible the co-creation of new knowledge (East, Fitzgerald, \& Heston, 2009). We adapted a poststructural feminist stance that allowed us to consciously work against being "routinized, static and predictable" and to "interrogate the enabling limits of [our] own practices, not to junk them but to shake them up" (Lather, 2006, p. 1). Destabilizing categories and provoking uncertainties (Britzman, 1993) freed us to consider deeper implications of creative engagement in and through self-study research.

Our understandings were reshaped over four months through online dialogue, via the virtual communication tools of email, Skype, and Dropbox. In this way, we extended and integrated our previous work on virtual bricolage, self-study (Pithouse-Morgan \& Samaras, 2014; Samaras et al., 2015) and co/autoethnographic research jamming (Coia \& Taylor, 2014).

The following transcription of an initial email conversation about how we might begin to explore methodological inventiveness shows our collective deliberation about the use of rich pictures, a form of visual brainstorming through drawing detailed pictures that can produce new ways of looking at an issue from multiple perspectives (Checkland, 2000). While rich pictures were developed for use in soft systems methodology (Checkland, 2000), they have also been used as a self-reflective research practice by Campbell Williams (1999), who drew a series of rich pictures to examine the progression of his teaching of a university business computing course over several years.

On May 28, 2015, Kathleen wrote to Lesley, Lesley, and Anastasia:

A visual research practice might work well for us to visualise our changing use of self-study through place, space and time. One possibility might be rich pictures.... I haven't used rich pictures as a self-study research practice before--but I'm always keen to try something new.... 
Lesley replied:

I. ... looked at the rich pictures site that Kathleen sent us (exciting). . . I I am not at all sure how this would work but it might be possible to map the terrain (history and present) and then layer on our experiences, lines of exploration and institutional involvement. This would provide rich context and a form of argumentation. ... As you can see, I am thinking aloud. I am not sure how visual argumentation works, but this is definitely an idea I am interested in pursuing.

Monica added:

I absolutely love the idea of the rich picture analysis. What a fantastic way to map-it almost feels like Deleuzian mapping [Deleuze \& Guattari, 1987] . . or rhizomatics [Strom \& Martin, 2013] . . . to me ... . Mapping seems like the perfect method when we talk about place, space, and time too. Excited to talk more about this! I wonder what digital space we could use to co-construct these maps!

And Anastasia concluded:

Wow! We're off so easily and I agree. It will be useful to map a terrain and us in it. ... we will go backwards and forwards. Let's start there then.

After further discussion, we decided that each of us would draw by hand a rich picture to map our personal experiences of creative engagement in self-study research. We then scanned and emailed our rich pictures to each other (for instance, Figure 1). We had a Skype call in which we explained our pictures and discussed the experience of drawing and viewing each other's pictures. We audio-recorded and typed notes on this conversation, and uploaded these files into a shared Dropbox folder. 


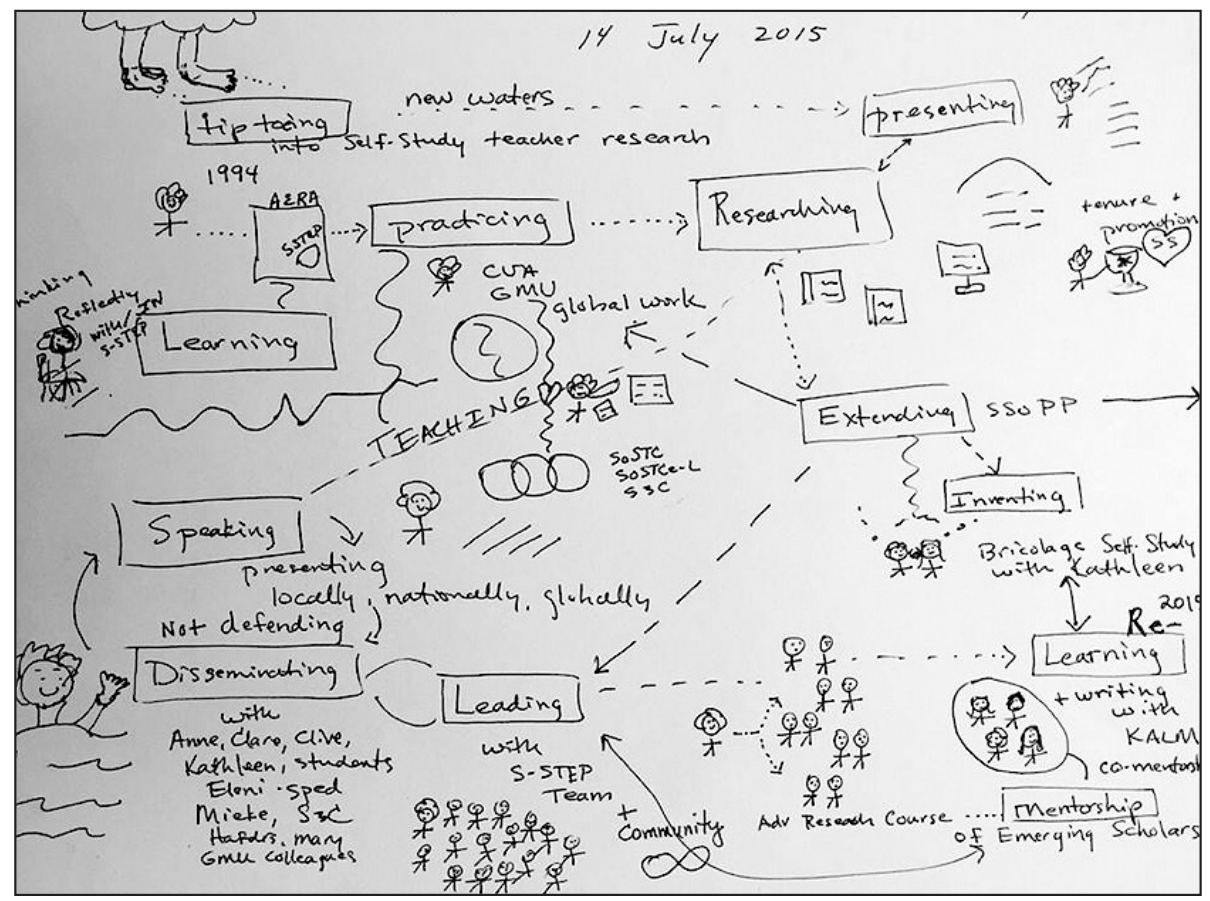

Fig 1: A rich picture drawn by Anastasia

Next, we each created a composite rich picture, in which we examined the contiguity of our meaning making through cutting and pasting together pieces from the four rich pictures. The composite rich picture was not a technique that we had read about or seen used; it was an innovative idea that developed through our virtual dialogue. We discovered that our composite pictures made visible the connections we found between our individual experiences to a collective one (for example, Figure 2). This process echoed the fundamental tenet of co/autoethnography: It allowed us to write into each others' lives (Taylor \& Coia, 2009) and create something new that collectively represented us as individuals as well as a group. 


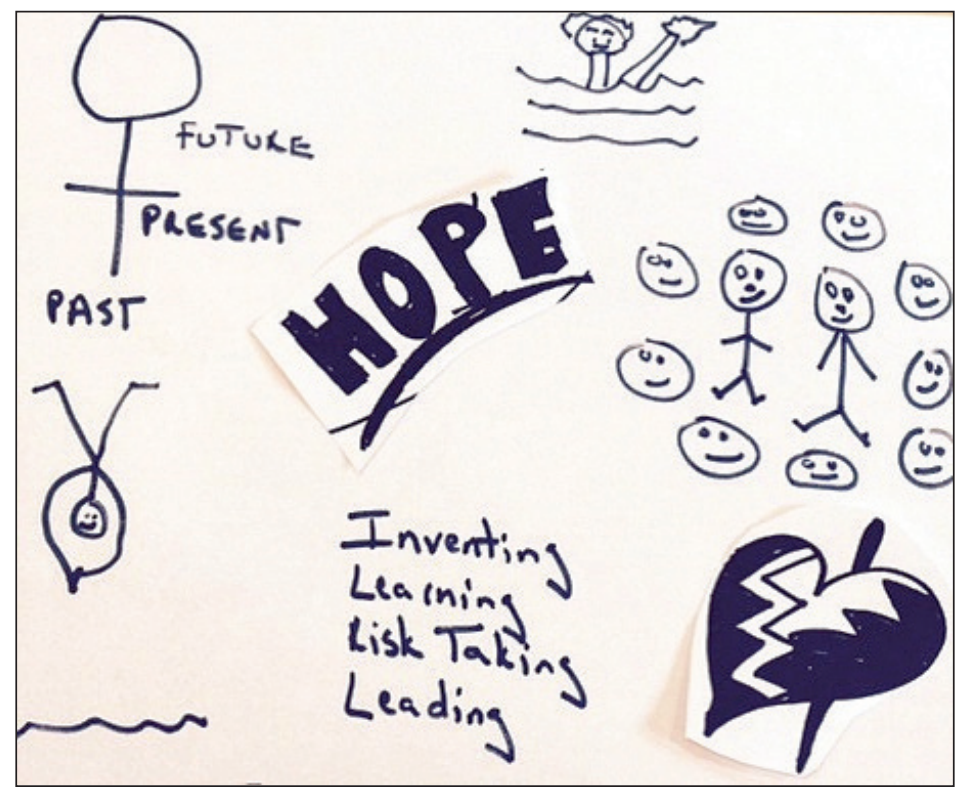

Fig. 2: A composite rich picture created by Monica

Further methodological inventiveness emerged. While working on her composite picture, Kathleen listened again to the audio recording of our Skype conversation. She was moved to create a found poem using words and phrases from our rich pictures and conversation as material for the poem, combining these in new ways with the intention of offering a holistic representation of our polyvocal dialogue (Butler-Kisber, 2002). She then emailed her composite picture and poem to the group and offered it for thought and extension. She wrote: "Here is my composite image and also a composite poem (I couldn't resist a poem after listening again to the audio of our poetic conversation...) ..." (Email communication, June 15, 2015).

\section{Gifts of This Moving Self-Study Stream}

A composite found poem

Tiptoeing into new waters

I set off on a long walk through the woods

Looking for ways in which change can happen

Diving into the deep

Falling in love

It could be dangerous... 
Changing my lens

Bringing in indigenous knowledge

Using the arts to understand my self

Writing into each other's lives

Changes the dynamic of what we do

We found it liberating

Finding a home

Believing that change is possible

Fully immersed

The questions are bigger

A healing process for wounded hearts

What can be learned from that pain?

An optimistic endeavour

Re-membering

Re-vitalising

It's not over

I'm not sure what's next

There's an element of the unknown...

Monica, drawing from her composite rich picture, as well as Kathleen's poem, then composed her own poem using words from the original rich pictures (see Figure 3 ). Inspired by the found poem and the general collective feeling of openness, she wrote a rhythmic poem that required a performance. As she composed it, she realized that it was an embodied expression that needed to be heard, rather than just read. She wrote the poem down and sent it to the group, but also performed and audiorecorded it, sharing the oral performance via Dropbox. Moving from Kathleen's found poem to her own performed poem involved what Siegel (1995) calls "transmediation" or "the act of translating meaning from one sign system to another" (p. 455). Being able to create a connection between different artistic modes is an effective demonstration of her reflective and generative process. She attached the following note to her audiorecorded poem: "Hello All: Attached is an audio recording of the found poem I created from our pictures--will send you the text and collage next. Inspired by all of you to try different mediums!" (Email communication, June 16, 2015). 
Exploring Methodological Inventiveness Through Collective Artful Self-Study Research

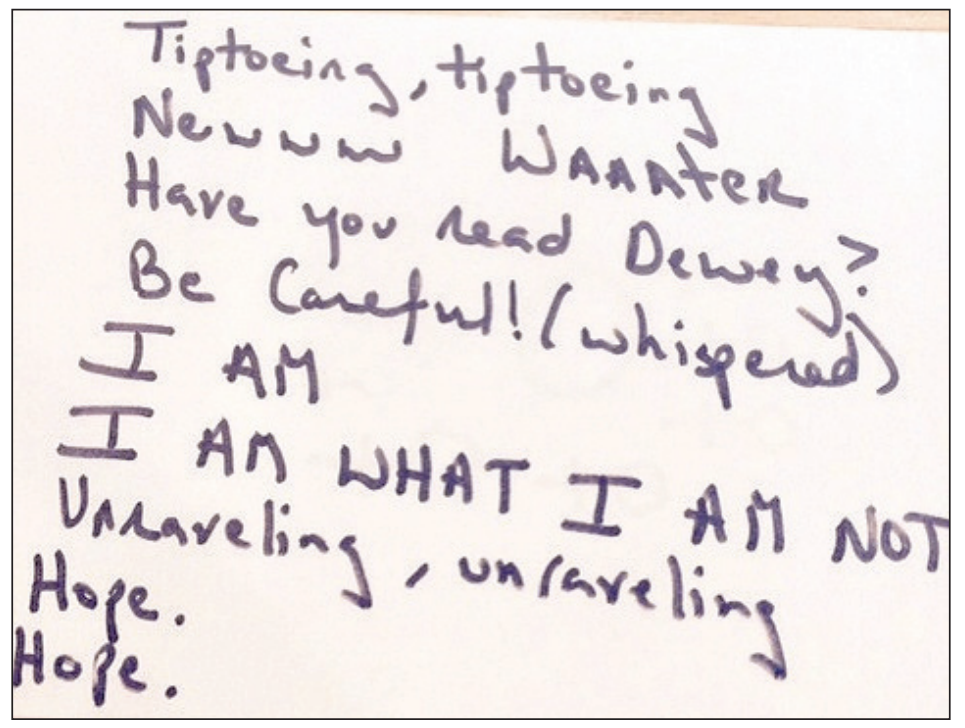

Fig. 3: Monica's poem: Tentatively jamming

In this trustful context, Anastasia was inspired to move in an improvisational manner to Kathleen's poetry and Monica's audio-taped choral reading. Anastasia e-mailed:

You have each inspired me to move into expressing our collective rich pictures ... through dance ... I have to try it I thought ... . I can get out of my text dependency for sure when I dance it. I danced it twice to whatever was playing and I open it with Monica's poem; See if you can find your voices in my expressions. (Email communication, June 17, 2015) (See Figure 4).

Anastasia shared a video via Dropbox of her improvised dance sequence, building upon and extending in a new way the evolving group dialogue. Lussier-Ley (2010) has described this kind of embodied self-study research as "dancing in the spaces in between what I know and what I am discovering" (p. 212). There were no directions, rules, or plans for the representation of Anastasia's data except to move to better understand the data and be part of something unique to academics; she was expressing her understanding of data by embodying it to build on, and contribute to, our collective data.

LEARNing Landscapes | Vol. 9, No. 2, Spring 2016 | 451 


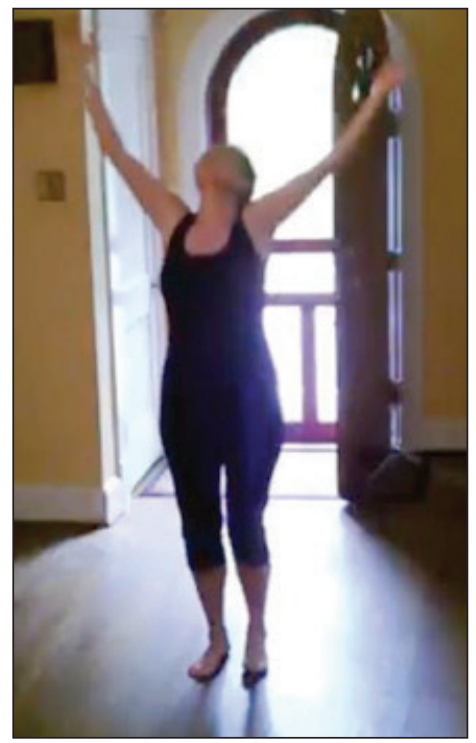

Fig. 4: A screenshot from the video of Anastasia's improvised dance sequence

\section{Understanding Methodological Inventiveness as Virtual Polyvocal Research Jamming}

Collective analysis of the data emerged through an open-ended Skype discussion about the composite pictures and the multiple artful responses. Again, we audiorecorded the conversation and typed meeting notes. In this conversation, we identified the "big ideas" about methodological inventiveness in self-study research that materialized as we "read" and responded to our collection of artful portrayals: the initial rich pictures; the composite pictures; the poems; and the dance sequence. We stepped back and listened and observed again-this time more to the generative process of building on each other's creativity and being inspired by each other and to the "so what and for whom" of our collective work. The irrelevant, or not pertinent, was shed in a barely perceptible "unravelling" (Figure 3, Tentatively Jamming, line 7) motion only visible when we reviewed the data. Building on key concepts from the earlier research that we had conducted as pairs, we named what was now taking place in our quartet as virtual polyvocal research jamming -an artful self-study research method (see also Pithouse-Morgan, Coia, Taylor, \& Samaras, forthcoming). 
Our emergent, dialogic meaning making of the series of rich pictures and audios, the dance video, and the notes taken during (and immediately following) our online meetings revealed four major elements of our enacting creative engagement in self-study:

\section{(Re)knowing in a Trusted Community}

Our work, which is representative rather than idiosyncratic, demonstrates how educational understanding grows through supportive listening and collective contributions: "Writing into each other's lives / Changes the dynamic of what we do" (Gifts of this Moving Self-Study Stream, lines 10-11). Knowledge is consciously co-created through a focus on the positive generation of openness to ideas. This collaboration allowed the generation of composite pictures, poems, oral performance, and dance, and other co-reflections that, we surmise, would not be available outside a trusting and trustworthy community. Our quartet rapidly became such a community and the virtual "creativity enabling space" (Sprague \& Parsons, 2012, p. 400) that took shape through our online interactions provided opportunities for inventive modes of expression through which we "experienced new depths and subtleties" (Peter Mann Pictures, 2015) of seeing, feeling, and thinking.

\section{Reciprocal Vulnerability}

Our research revealed a contagious courage to engage with unfamiliar, artful tools. Although we had not worked together as a quartet before, we willingly made ourselves vulnerable by "diving" (Gifts of this Moving Self-Study Stream, line 4) into "Newww Waaater" (Figure 3, Tentatively Jamming, line 2), resulting in the production of meaningful work. As we looked back at what we produced, the ways in which we made ourselves vulnerable to each other were palpable, but also in need of some reflection. Part of the reason for our ability to fall so quickly into this shared openness could be the nature of the wider self-study research community, which is known for embracing candid discussions of self and its relation to practice, often through artful means (Weber, 2014; Weber \& Mitchell, 2004). There was also a deep measure of respect between the authors, each of whom is practiced in collaborative research, which helped propel us into a positive vulnerability. This enabled us to explore in a productive way aspects of our work that could not be reached by other more conventional research methods. Gulla (2014) highlights this as the "value of the willingness to channel one's vulnerability through the conduit of creativity" (p. 143). 


\section{Shared Improvisation}

We found that methodological inventiveness is about standing back and listening for resonance and connection: "I AM / I AM WHAT I AM NOT" (Figure 3, Tentatively Jamming, lines 5-6). As with musical improvisation or jamming, it is about what you add when working with others (Harris, 2011). This is possible because of an often "unspoken communication" (Coia \& Taylor, 2014) that involves active listening to one another, thus "allowing creativity to flow" (Harris, 2001) through space and time, across states and continents. It also occurs when each participant's contribution is honoured. It is "an optimistic endeavour" (Gifts of this Moving Self-Study Stream, line 19) that involves openness to the unpredictable and a faith that shared improvisation will produce something new that offers insight. Improvisation is a seductive theme, but requires much in terms of relevant knowledge of the art form on which the improvisation riffs. Our improvisation as a quartet drew not only on our collective knowledge of self-study and its characteristic methodological inventiveness, but also on our earlier paired explorations of artful research practices such as co/autoethnography (Taylor \& Coia, 2009), improvised dialogue (Coia \& Taylor, 2014), and collective poetic inquiry (Pithouse-Morgan \& Samaras, 2014; Samaras et al., 2015).

\section{Methodological Innovation as Joyful Wonder}

Our artful portrayals expressed a sense of joyful wonder and pleasure at stretching and challenging ourselves and gaining new insights: "We found it liberating / Re-vitalising" (Gifts of this Moving Self-Study Stream, lines 12, 21). We eagerly looked for and quickly responded to each other's emails as if to capture a moment in time for each of us. The enjoyment of working together, of managing tensions between self and community, is characteristic of collective self-study research (Davey \& Ham, 2009). Our rich pictures are a metaphor for how our practice is individuated and deeply connected. Anastasia's improvisational dance pictured above (Figure 4) reflects our joy in lifting ourselves beyond the courses often run in research that just dig deeper and straighter as they plough along the same furrows. Being able to see and enjoy the new patterns formed when we look up together at what has emerged from our virtual polyvocal research jamming is an important result of our collective artful inquiry. 


\section{Moving Into the Unknown}

Our collaborative inquiry was enlivened by an optimistic commitment to trying out artful ways of doing, understanding, and representing that push the boundaries of learning and knowing within and beyond the genre of self-study research. Our "animating, embodying [adventure]" (Badley, 2015, p. 717) of creative engagement was not "innovation for the sake of innovation" (Mitchell, 2016, p. 181). Its purpose was to deepen and extend our shared reflection, analysis, and communication. We have come to see how finding imaginative ways to express and make sense of our insights together can allow these to develop, while simultaneously inviting responses from each other. Through collective artful self-study, we learned that creative engagement can enter into the research process in unanticipated ways; these are ways that might be overlooked if we are not paying careful attention or are not open to surprises. We see such openness to extemporaneity as adding to the methodological characteristics and guideposts that have been offered by the self-study scholarly community (for example, LaBoskey, 2004; Lunenberg \& Samaras, 2011). A dynamic interplay between convention and spontaneity can offer vital impetus and orientation for artful inquiry. Our work aligned with a view of creativity in teaching, learning, and researching as "refreshing and ... extending knowledge, and that this refreshment is inhibited if we are compelled to work within overly constraining expectations_of ourselves and of others" (Katz, 2015, p. 19). Our virtual polyvocal research jamming is a microcosm of how we discover artful methods to advance scholarship and practice when we extend outwards from "the shoulds" of research method to the extemporaneity of "why nots?"

The visual artist Sargy Mann (Peter Mann Pictures, 2015) has described how the human capacity for artistic expression and perception has developed over time because of methodological inventiveness in various art forms. Likewise, educational understanding evolves when we dare to imagine and enact innovative possibilities for "a new vision of learning places as creativity enabling spaces" (Sprague \& Parsons, 2012 , p. 400). This can happen when we, in dialogue with others, experience our selves, our practice, and our contexts as fluid and full of possibility. Enhanced awareness of the shifting nature of our selves and our knowing can heighten our consciousness that some change for the better is almost always within reach. When hope and optimism are supported by experiential wisdom gained through shared creative engagement, we can confidently make a qualitative difference in our work with students and colleagues, and more broadly at the level of programs and policy. Virtual polyvocal research jamming offers us the priceless gifts of collective intuition, spontaneity, and improvisation. We take these with us, and offer them to our students, colleagues, and readers, as we move into the unknown. 


\section{References}

Badley, G. (2014). Six characters in search of an author: A qualitative comedy in the making. Qualitative Inquiry, 20(5), 659-667.

Badley, G. F. (2015). Playful and serious adventures in academic writing. Qualitative Inquiry, 21(8), 711-719.

Berry, M. (2014). Self-Study of Teacher Education Practices (S-STEP). In R. Gunstone (Ed.), Encyclopedia of Science Education (pp. 964965). Dordrecht: Springer.

Britzman, D. P. (1993, October). Is there a queer pedagogy?: Or, stop being [acting?] straight! Paper presented at the Journal of Curriculum Theorizing Conference, Dayton, $\mathrm{OH}$.

Bullough, R. V. Jr, \& Gitlin, A. D. (1995). Becoming a student of teaching: Methodologies for exploring self and school context. New York: Garland.

Butler-Kisber, L. (2002). Artful portrayals in qualitative inquiry: The road to found poetry and beyond. Alberta Journal of Educational Research, 48(3), 229-239.

Campbell Williams, M. (1999). Rich pictures on the path towards systemic being. Systems Research and Behavioral Science, 16(4), 369-373.

Checkland, P. (2000). Soft systems methodology: A thirty year retrospective. Systems Research and Behavioral Science, 17, S11-S58.

Coia, L., \& Taylor, M. (2009). Co/autoethnography: Exploring our teaching selves collaboratively. In D. Tidwell, M. Heston, \& L. Litzgerald (Eds.), Research methods for the self-study of practice (pp. 3-16). Dordrecht, The Netherlands: Springer.

Coia, L., \& Taylor, M. (2014). A co/autoethnography of feminist teaching: Nomadic jamming into the unpredictable. In M. Taylor \& L. Coia, (Eds.) (2014). Gender, feminism and queer theory in the self-study of teacher education practices (pp. 157-168). Rotterdam: Sense Publishers.

Dadds, M., \& Hart, S. (2001). Doing practitioner research differently. London: RoutledgeFalmer.
Davey, R., \& Ham, V. (2009). Collective wisdom: Team-based approaches to self-study in teacher education. In C. A. Lassonde, S. Galman, \& C. Kosnik (Eds.). Self-study research methodologies for teacher educators (pp. 187-203). Rotterdam: Sense Publishers.

Deleuze, G., \& Guattari, F. (1987). A thousand plateaus: Capitalism and schizophrenia. Minneapolis, MN: University of Minnesota Press.

East, K., Fitzgerald, L. M., \& Heston, M. L. (2009). Talking teaching and learning: Using dialogue in self-study. In D. L. Tidwell, M. L. Heston, \& L. M. Fitzgerald. (Eds.), Research methods for the self-study practice (pp. 55-72). Dordrecht: Springer

Garbett, D., \& Ovens, A. (Eds.). (2014). Changing practices for changing times: Past, present and future possibilities of self-study research. Proceedings of the Tenth International Conference on the Self-Study of Teacher Education Practices, Herstmonceux Castle, UK. Auckland: University of Auckland.

Gulla, A.N. (2014). Myth, metaphor, and metacognition: Shaping voice and identity through poetry in teacher education. LEARNing Landscapes, 8(1), 139-152. Retrieved from http://www.learninglandscapes.ca/images/ documents/II-no15/angulla.pdf

Harris, S. (2001, November). [Video file] There are no mistakes on the bandstand. Retrieved from http://www.ted.com/talks/stefon_ harris_there_are_no_mistakes_on_the_ bandstand?language $=$ en

Katz, L. (2015). Doubt, ambivalence, and creativity in academia. Journal of Artistic and Creative Education, 9(1), 8-21.

LaBoskey, V. K. (2004). The methodology of selfstudy and its theoretical underpinnings. In J. J. Loughran, M. L. Hamilton, V. K. LaBoskey, \& T. Russell (Eds.), International handbook of self-study of teaching and teacher education practices (Vol. 2, pp. 817-869). Dordrecht: Kluwer Academic Publishers.

Lather, P. (2006, October). (Post)Feminist methodology: Getting lost OR a scientificity we can bear to learn from. Paper presented at the Research Methods Festival, Oxford, England. 
Latta, M. M., \& Buck, G. (2007). Professional development risks and opportunities embodied within self-study. Studying Teacher Education, 3(2), 189-205.

Loughran, J. (2010). Seeking knowledge for teaching teaching: Moving beyond stories. Studying Teacher Education, 6(3), 221-226.

Loughran, J. J. (1996). Developing the reflective practitioner: Learning about teaching and learning through modeling. London: Falmer Press.

Lunenberg, M., \& Samaras, A.P. (2011). Developing a pedagogy for teaching selfstudy research: Lessons learned across the Atlantic. Teaching and Teacher Education, 27(5), 841-850. doi:10.1016/j.tate.2011.01.008

Lussier-Ley, C. (2010). Dialoguing with body: A self-study in relational pedagogy through embodiment and the therapeutic relationship. The Qualitative Report, 15(1), 197-214.

Mitchell, C. (2016). Autoethnography as a wide-angle lens of looking (inward and outward): What difference can this make to our teaching? In D. Pillay, I. Naicker, \& K. Pithouse-Morgan (Eds.), Academic autoethnographies: Inside teaching in higher education (pp. 175-189). Rotterdam, The Netherlands: Sense.

Peter Mann Pictures (Producer). (2015). [Video file] Sargy Mann: More. Different. Better. Thoughts towards a talk. Retrieved from https://vimeo.com/130542757

Pithouse-Morgan, K., \& Samaras, A. P. (2014). Thinking in space: Learning about dialogue as method from a trans-continental conversation about trans-disciplinary self-study of professional practice. In D. Garbett \& A. Ovens (Eds.), Changing practices for changing times: Past, present and future possibilities of self-study research. Proceedings of the Tenth International Conference on the Self-Study of Teacher Education Practices (pp. 167-170). Herstmonceux Castle, UK: University of Auckland.

Pithouse-Morgan, K., \& Samaras, A. P. (Eds.). (2015). Polyvocal professional learning through self-study research. Rotterdam: Sense Publishers.
Pithouse-Morgan, K., Coia, L., Taylor, M., \& Samaras, A. (Forthcoming). Polyvocal research jamming: A quartet enacting methodological inventiveness in self-study. In D. Garbett \& A. Ovens (Eds.), Enacting selfstudy as methodology for professional inquiry. Proceedings of the Eleventh International Conference on the Self-Study of Teacher Education Practices. Auckland: University of Auckland.

Russell, T., \& Korthagen, F. (1995). Teachers who teach teachers: Reflections on teacher education. London: Falmer Press.

Samaras, A. P., Karczmarczyk, D., Smith, L., Woodville, L., Harmon, L., Nasser, I., et al. (2014). The shark in the vitrine: Experiencing our practice from the inside out with transdisciplinary lenses. Journal of Transformative Education, 1-21.

Samaras, A. P., Pithouse-Morgan, K., Chisanga, T., Conolly, J., Constantine, L. S., Meyiwa, T., et al. (2015). Breathing under water: A transcontinental conversation about the "why" of co-facilitating transdisciplinary self-study learning communities. In K. PithouseMorgan \& A. P. Samaras (Eds.), Polyvocal professional learning through self-study research (pp. 231-252). Rotterdam: Sense Publishers.

Siegel, M. (1995). More than words: The generative power of transmediation for learning. Canadian Journal of Education, 20(4), 455-475.

Sprague, M., \& Parsons, J. (2012). The promise of creativity. LEARNing Landscapes, 6(1), 389-407. Retrieved from http://www. learninglandscapes.ca/images/documents/ II-no11/mesprague.pdf

Strom, K.J., \& Martin, A. D. (2013). Putting philosophy to work in the classroom: Using rhizomatics to deterritorialize neoliberal thought and practice. Studying Teacher Education, 9(3), 219-235.

Taylor, M., \& Coia, L. (2006). Revisiting feminist authority through a co/autoethnographic lens. In D. Tidwell \& L. Fitzgerald (Eds.), Selfstudy and diversity (pp. 51-70). Rotterdam: Sense Publishers. 
Taylor, M., \& Coia, L. (2009). Co/autoethnography: Investigating teachers in relation. In C. Lassonde, S. Galman, \& C. Kosnik (Eds.), Self-study research methodologies for teacher educators (pp. 169-186). Rotterdam: Sense Publishers.

Weber, S. (2014). Arts-based self-study: Documenting the ripple effect. Perspectives in Education, 32(2), 21-36.

Weber, S., \& Mitchell, C. (2004). Using visual and artistic modes of representation for selfstudy. In J. J. Loughran, M. L. Hamilton, V. K. LaBoskey, \& T. Russell (Eds.), International handbook of self-study of teaching and teacher education practices (Vol. 2, pp. 979-1037). Dordrecht: Kluwer Academic Publishers.
Whitehead, J. (2004). What counts as evidence in self-studies of teacher education practices? In J. J. Loughran, M. L. Hamilton, V. K. LaBoskey, \& T. Russell (Eds.), International handbook of self-study of teaching and teacher education practices (Vol. 2, pp. 871-903). Dordrecht: Kluwer Academic Publishers.

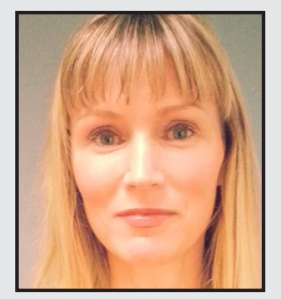

Kathleen Pithouse-Morgan is a senior lecturer in Teacher Development Studies in the School of Education at the University of KwaZulu-Natal, South Africa. She is the current lead investigator of the Transformative Education/al Studies (TES) project, which aims to develop self-study research capacity in a transdisciplinary, multi-institutional professional learning community. Kathleen is lead editor of two books on transdisciplinary self-study research: Making Connections: Self-Study \& Social Action (Pithouse, Mitchell, \& Moletsane, 2009) and Polyvocal Professional Learning through Self-Study Research (Pithouse-Morgan \& Samaras, 2015). She served as secretary of the Self-Study of Teacher Education Practices (S-STEP) Special Interest Group (SIG) of the American Educational Research Association (AERA), 2012-2014. 


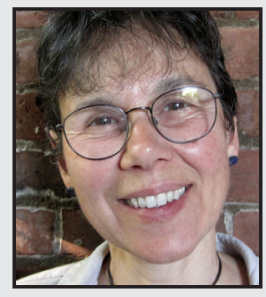

Lesley Coia is a Professor of Education at Agnes Scott College, a liberal arts college for women in Atlanta, Georgia in the United States. Lesley is a long-term member of the SelfStudy of Teacher Education Practices Special Interest Group of the American Educational Research Association (AERA), where she first met Kathleen Pithouse-Morgan and Anastasia Samaras. She has collaborated with Monica Taylor on many research projects since they worked together at Wagner College in the late 1990s. Their latest publication is the co-edited collection of papers, Gender, Feminism, and Queer Theory in the Self-Study of Teacher Education Practices (2014).

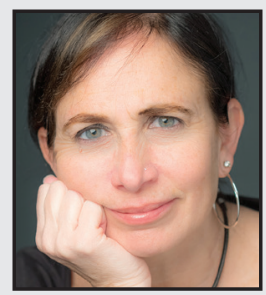

Monica Taylor is an Associate Professor in the Secondary and Special Education department at Montclair State University, in Montclair, New Jersey in the United States. For the past 15 years, she has worked collaboratively with Lesley Coia to develop co/autoethnography, a self-study research methodology. In their early years of this work, they discovered the Self-Study of Teacher Education Practices Special Interest Group of the American Educational Research Association (AERA), and have been involved with the group ever since. In 2014, they co-edited the volume, Gender, Feminism, and Queer Theory in the SelfStudy of Teacher Education Practices. Some of Monica's other publications include: A Year in the Life of an Urban Teacher Residency: Reinventing Teacher Education (Taylor \& Klein, 2015) and Whole Language Teaching, Whole Hearted Practice: Looking Back, Looking Ahead (Taylor, 2007). 


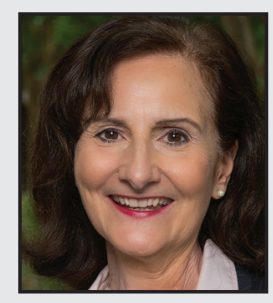

Anastasia P. Samaras is Professor of Education in the College of Education and Human Development at George Mason University, United States. Her signature work in self-study research methodology includes Polyvocal Professional Learning Through Self-Study Research (Pithouse-Morgan \& Samaras, 2015), Self-Study Teacher Research (Samaras, 2011), and Learning Communities in Practice (Samaras, Kosnik, Freese, \& Beck, 2008). A Fulbright Scholar, she is recipient of a Dissertation Research Award, Outstanding Scholar Award, and a frequent Visiting SelfStudy Scholar. Anastasia served as chair of Self-Study of Teacher Education Practices SIG 2013-2015 and is Co-PI of two National Science Foundation funded teaching projects. She is currently studying her role facilitating neo-Vygotskian-based applications in transdisciplinary self-study groups for faculty development. 